\title{
Evolutionary dynamics shape two passive defensive mechanisms in Neotropical snake radiations
}

\author{
Alexandro Marques Tozetti, ${ }^{1}$ Sergio Augusto Abrahão Morato, ${ }^{2}$ Renato Silveira Bérnils, ${ }^{3}$ Daniel \\ Loebmann, ${ }^{4}$ Luís Felipe Toledo, ${ }^{5}$ Russell Gray, ${ }^{6}$ and Omar M. Entiauspe-Neto ${ }^{4}$ \\ ${ }^{1}$ Universidade do Vale do Rio dos Sinos - UNISINOS. 93022-000, São Leopoldo, RS, Brazil. \\ 2 Instituto de Ciência e Tecnologia em Biodiversidade. 83430-000, Campina Grande do Sul, PR, Brazil. \\ ${ }^{3}$ Universidade Federal do Espírito Santo, Centro Universitário Norte do Espírito Santo. 29932-540, São Mateus, ES, Brazil. \\ ${ }^{4}$ Universidade Federal do Rio Grande, Instituto de Ciências Biológicas, Laboratório de Vertebrados. 96203-900, Rio Grande, \\ RS, Brazil. E-mail: omarentiauspe@ hotmail.com. \\ ${ }^{5}$ Universidade Estadual de Campinas, Instituto de Biologia, Departamento de Biologia Animal, Laboratório de História Natural \\ de Anfíbios Brasileiros (LaHNAB). 13083-862, Campinas, SP, Brazil. \\ ${ }^{6} 705$ Alligator Ranch Rd. New Smyrna Beach, 32168, Florida, USA.
}

\begin{abstract}
Evolutionary dynamics shape two passive defensive mechanisms in Neotropical snake radiations. We mapped the distribution of two defensive behaviors (balling and head hiding) of Neotropical snakes to evaluate its distribution in distinct phylogenetic groups. Balling behavior was observed in 58 out of the 167 examined species across seven families. Head hiding was observed in a total of 100 species across nine families. From the high prevalence of balling behavior in basal groups of snakes, such as Anomalepididae, Boidae, Leptotyphlopidae, Tropidophiidae, and Typhlopidae, and the low prevalence among species of recent diversification radiations, such as Elapidae and Viperidae, we suggest that this behavior evolved in basal groups and persisted in some derived taxa. Balling was not observed in association with other defensive strategies, while head hiding can occur in combination with caudal elevation, caudal vibration, and body flattening. Therefore, head hiding, in contrast to balling behavior, presents itself as putatively more flexible, as it should allow for an escalated degree of defensive displays.
\end{abstract}

Keywords: Balling, defensive behavior, evolution, head hiding, Neotropical snakes, predation.

\section{Resumo}

Dinâmicas evolutivas moldam dois mecanismos de defesa passivos em radiações de serpentes neotropicais. Neste estudo, mapeamos a distribuição de dois mecanismos defensivos (embolar e esconder a cabeça) em serpentes neotropicais, visando observar sua distribuição em relação a diferentes grupos filogenéticos. O comportamento de embolar foi observado em 58 das 167 espécies 
analisadas, estando presente em sete famílias. Esconder a cabeça foi observado em 100 espécies distribuídas em nove famílias. O predomínio do comportamento de embolar em grupos basais de serpentes, como Anomalepididae, Boidae, Leptotyphlopidae, Tropidophiidae e Typhlopidae, e sua pouca incidência em espécies pertencentes a famílias mais recentes, como Elapidae e Viperidae, nos levam a sugerir que esse comportamento originou-se em grupos basais, persistindo em grupos derivados. O comportamento de embolar não foi observado em associação com outras estratégias defensivas, enquanto que esconder a cabeça ocorreu em combinação com elevação de cauda, vibração de cauda e achatamento do corpo. Desse modo, esconder a cabeça apresenta-se como putativamente mais flexível do que embolar, uma vez que permitiria a exibição escalonada de outros comportamentos defensivos.

Palavras-chave: comportamento defensivo, esconder a cabeça, embolar, evolução, predação, serpentes neotropicais.

\section{Introduction}

Avoiding predation is a fundamental challenge to living organisms (Dawkins and Krebs 1979, Greene 1988, Ruxton et al. 2004). Hence, they have evolved a wide range of defensive strategies to reduce predation risk. Understanding and describing different defensive mechanisms may provide insights on evolutionary trends of predator/prey relationships among taxa and defensive character selection pressures (Greene 1983). Squamates have diverse anti-predator mechanisms, including cryptic coloration, mimicry, aposematism, and various behavioral displays in order to avoid predation (Greene 1973, Tozetti et al. 2009, Lewis and Lewis 2010, Pough et al. 2016). Two of the most iconic defensive behaviors in snakes involve balling and head hiding. Balling consists of rolling the body with the head hidden, forming a sphere (Bustard 1969, Mitchell 1978; Figure 1). In addition to protecting the head, balling has been considered to be especially effective for snakes inside burrows (Mitchell 1978). Head hiding is the ability of concealing the head under the snake's own body, ultimately confounding the predator or avoiding predation (Tozetti et al. 2009). These behaviors may provide snakes with important generalized protection against consumption, since snakes are potential prey for predatory mammals, birds, other reptiles (including snakes), large amphibians, and even invertebrates (Greene 1997).
Although defensive snake tactics are apparently well documented (Greene 1988), relationships between defensive tactics and their evolutionary dynamics have not yet been tested under a phylogenetic framework, leaving an important gap as to why and how these tactics have evolved in snakes. Both behaviors (balling and head hiding) also seem to be phylogenetically widespread among snakes, and available information is largely scattered (Bustard 1969). In order to improve our knowledge on snake defensive behaviors, we present a set of original data on balling and head hiding behaviors, with special focus on Brazilian species (several of which are widely distributed in the Neotropical region), while also providing comments on their phylogenetic relationships.

\section{Materials and Methods}

Our dataset was obtained during 33 years of observations made in field trips in Brazil from 1985 to 2018. We also compiled some personal information kindly provided by Brazilian herpetologists (see Acknowledgments section). We defined balling as the behavior when the snake forms a ball with its body when approached by the researcher or during handling (Mitchell 1978), and head hiding when the animal conceals its head with other parts of the body when touched or handled (Tozetti et al. 2009). We compiled data from 167 snake species of 10 families, representing about $42 \%$ of total of 

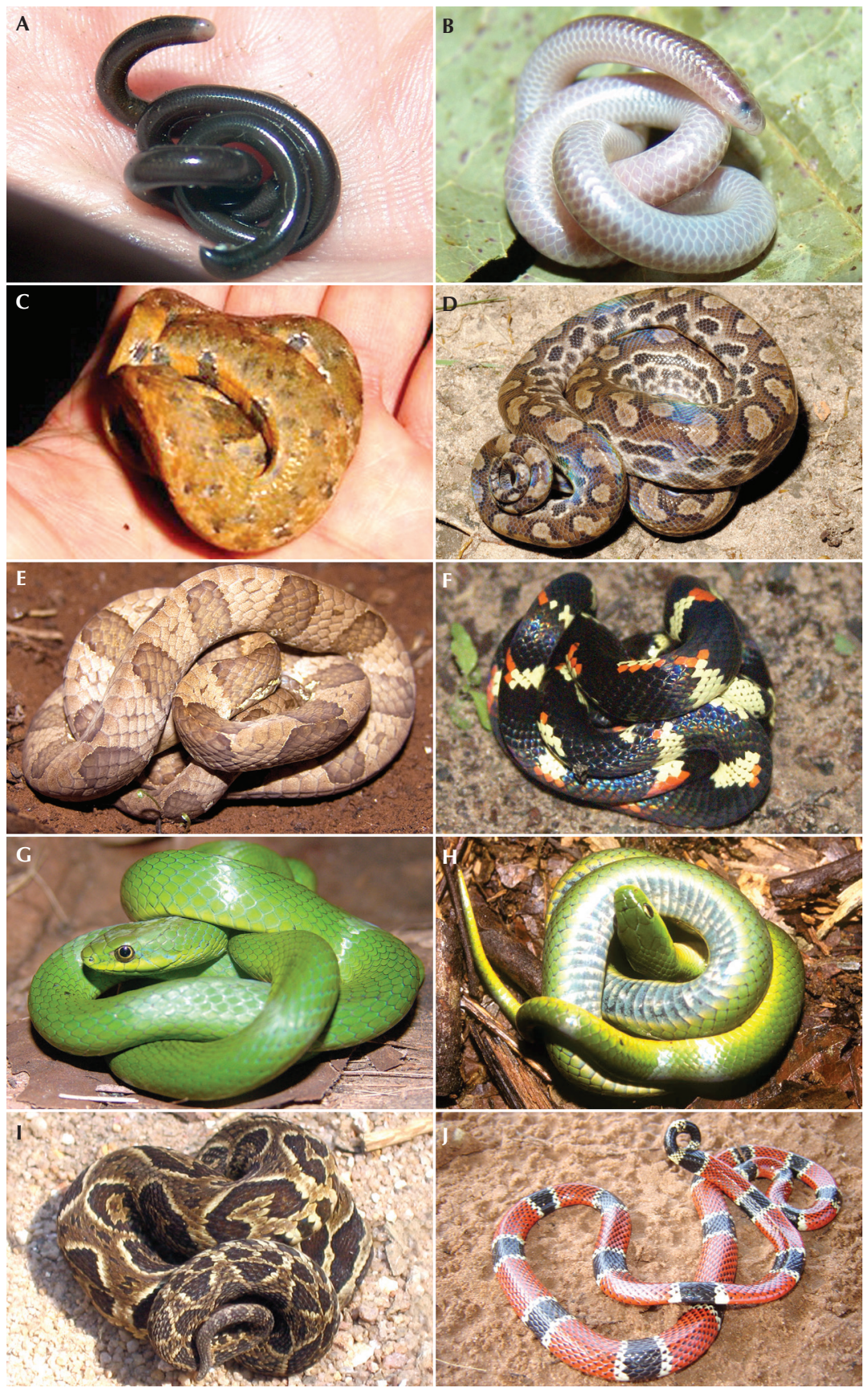

Figure 1. Defensive behavior displayed by distinct snake groups: Liotyphlops ternetzii (A), Siagonodon brasiliensis (B), Tropidophis paucisquamis (C), Epicrates assisi (D), Dipsas bucephala (E), Siphlophis worontzowi (F), Philodryas olfersii $(\mathbf{G})$, Erythrolamprus atraventer $(\mathbf{H})$, Bothrops fonsecai $(\mathbf{I})$, and Micrurus corallinus (J). Photograph credits: Daniel Loebmann (A, B, E, G), Fernanda Stender (C), Paula H. Valdujo (D), Luís Felipe Toledo $(F, J)$, and Julián Faivovich $(H)$. 
Brazilian snake richness (Costa and Bérnils 2018). We included in our analysis 114 species that exhibited balling and/or head hidden behaviors. Taxonomy adopted follows Costa and Bérnils (2018).

For ancestral likelihood reconstruction of head hiding and balling behaviors, we used the rotl package (Michonneau et al. 2016) to incorporate our list of species $(N=114)$ into an existing phylogenetic tree file of snake species provided as supplementary material from Figueroa et al. (2016) using the castor package (Louca and Louca 2017) for the tree subset. The resulting matches for the existing species in the phylogeny included 80 species. We used the phylotools package (Revell 2012) for the Ancestral Character Estimation (ACE) and mapping maximum likelihood visualizations using the two behaviors as independent binary datasets (i.e., 1 = species exhibits the behavior; 0 $=$ species did not exhibit the behavior) at $95 \%$ confidence. While we used this method for ancestral representation, the original dataset of 114 species was used to quantitatively report the overall distribution of behaviors in our study species.

\section{Results}

Ancestral reconstruction of head hiding and balling behavior showed an inverse relationship trend in species (Figure 2, inset ACE graph). Head-hiding behavior appears to be widespread with $88 \%$ of species exhibiting the behavior, and ancient in snake lineages according to its presence throughout the root state. Contrastingly, only $51 \%$ of species exhibited balling behavior and, as the reconstruction shows, is a relatively recent development throughout the clades that is somewhat unevenly distributed. However, the vast majority of snakes that exhibited head hiding behavior did not exhibit balling behavior with few exceptions in each clade.

Based on the Brazilian snakes' species list (Costa and Bérnils 2018), the most well represented families in our study were Boidae,
Dipsadidae, Tropidophiidae, and Viperidae (Table 1). Balling was observed in 58 out of the 167 examined species and distributed in seven families (Table 1, Figure 1). This behavior was observed in all species of Anomalepididae, Leptotyphlopidae, Tropidophiidae, and Typhlopidae. We did not observe balling behavior in Colubridae, Elapidae, and Aniliidae (Tables 1 and 2).

Head hiding was observed in a total of 100 species distributed into nine families (Tables 1 and 2; Figure 1), accounting for $58.9 \%$ of the species examined and among $26 \%$ of the Brazilian species. This behavior was absent in Leptotyphlopidae, but present in all Elapidae, Tropidophiidae, Typhlopidae, and Aniliidae species examined, in addition to $87.5 \%$ of Boidae and $64.6 \%$ of Dipsadidae species. This behavior was also recorded in $18.2 \%$ of Colubridae, $50 \%$ of Anomalepididae, and $47.6 \%$ of Viperidae species (Tables 1 and 2).

\section{Discussion}

From the observation of high percentage of balling in the basal families Anomalepididae, Boidae, Leptotyphlopidae, Tropidophiidae, and Typhlopidae it appears to be ancestral (Greene 1997). Also, this behavior is much rarer in more recently derived families, such as Elapidae and Viperidae. Instead, Elapidae and Viperidae have evolved defensive mechanisms largely based on the ability to deliver venomous strikes. It is possible that head hiding was positively selected over balling behavior in these families, as this might allow the species to strike more actively. Therefore, we suggest that balling was present in an ancestral and was lost several times across the phylogenetic tree, especially among the derived venomous taxa. Still, further observations under natural conditions are warranted to evaluate if this relatively rare behavior is not present in cryptic or poorly known viperid and elapid taxa.

Alternatively, balling behavior may be related to snake morphology and anatomy. This behavior requires great body contraction and it 

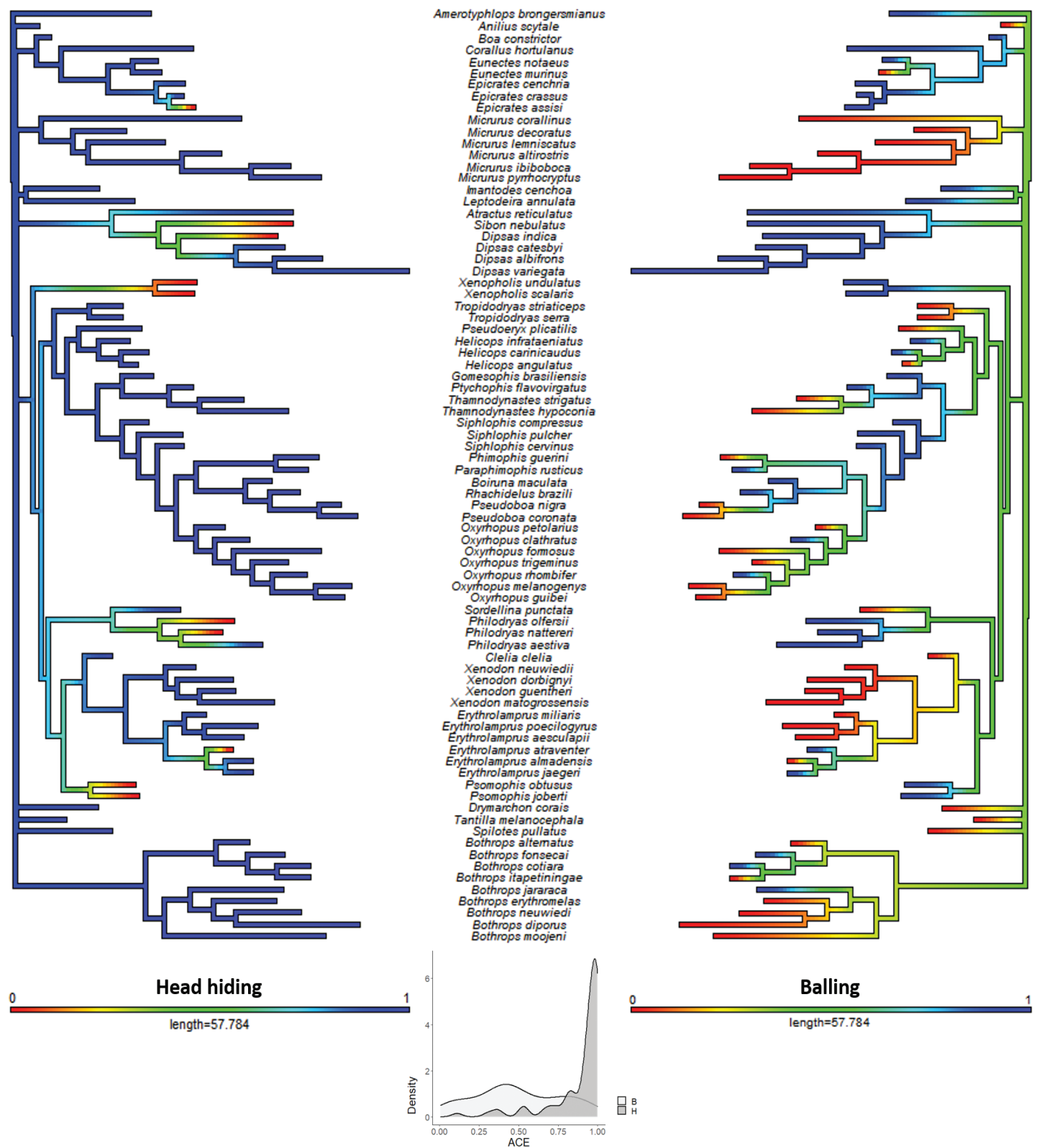

只古

Figure 2. Ancestral state reconstruction of Neotropical snake species $(N=80)$ exhibiting contrasting differences of head hiding and balling defensive behaviors. Density of ancestral character estimates provided for distribution comparisons of the two behaviors. 
Table 1. Balling behavior and head hiding behaviors in snake families, the percentage and number of species tested in each family. For the Brazilian list category values are presented as percentage of studied species (total species in Brazil/species tested). For the defensive behaviors, values are presented as the percentage of species that displayed the behavior (species tested/species that displayed the behavior).

\begin{tabular}{lccc}
\hline Family & Brazilian list & Balling behavior & Head hiding \\
\hline Aniliidae & $100 \%(1 / 1)$ & $0 \%(1 / 0)$ & $100 \%(1 / 1)$ \\
Anomalepididae & $28.6 \%(7 / 2)$ & $100 \%(2 / 2)$ & $50 \%(2 / 1)$ \\
Boidae & $66.7 \%(12 / 8)$ & $87.5 \%(8 / 7)$ & $87.5 \%(8 / 7)$ \\
Colubridae & $64.7 \%(34 / 22)$ & $0 \%(22 / 0)$ & $18.2 \%(22 / 4)$ \\
Dipsadidae & $41.1 \%(241 / 99)$ & $43.4 \%(99 / 43)$ & $68.7 \%(99 / 68)$ \\
Elapidae & $25.9 \%(27 / 7)$ & $0 \%(7 / 0)$ & $100 \%(7 / 7)$ \\
Leptotyphlopidae & $7.1 \%(14 / 1)$ & $100 \%(1 / 1)$ & $11 / 0)$ \\
Tropidophiidae & $100 \%(1 / 1)$ & $100 \%(1 / 1)$ & $100 \%(1 / 1)$ \\
Typhlopidae & $16.7 \%(6 / 1)$ & $100 \%(1 / 1)$ & $100 \%(1 / 1)$ \\
Viperidae & $75 \%(28 / 21)$ & $14.3 \%(21 / 3)$ & $47.6 \%(21 / 10)$ \\
Total & $43.9 \%(371 / 163)$ & $30.7 \%(163 / 50)$ & $58.9 \%(163 / 96)$ \\
\hline
\end{tabular}

would easier for stronger species (such as the constrictors) or those with small scales, which allow more flexibility. This is in agreement with our findings. For example, boids such as Python regius (Shaw, 1802) and Calabaria reinhardtii (Schlegel, 1851) (LFT pers. obs.) in the Neotropical (Table 2) and African regions are both thick-bodied snakes with smooth scales that display balling behavior. However, because both boids and tropidophiids are basal families where most members have thick bodies and smooth scales, the relative importance of these two traits to balling behavior is difficult to separate.

Considering the last review presented by Greene (1988), it is imperative to affirm that defensive behaviors of snakes are poorly documented and widely scattered in the literature, in need of a wide review, although this was not the scope of our study. A comprehensive review about balling and head hiding behaviors would complement our results, providing a broader dataset, which will allow a deeper understanding of the occurrence of defensive strategies among snakes and tracing accurately their evolution. However, negative results regarding the display of a behavior do not guarantee it is absent in the species, or other higher taxonomic levels (such as genus, tribe or family). Some snakes exhibit both behaviors, but the distribution of the occurrence of the displays among snake families is variable.

Mitchell (1978) hypothesized that balling is displayed by snakes inside holes or burrows, as it would be difficult to remove a ball from an opening that was only large enough to allow a snake to enter. However, this does not seem to be the case of Neotropical snakes. All individuals were not in holes when displaying this behavior and many are arboreal species that do not occupy burrows. Most of our suggestions still need experimentation and corroboration, but they may provide a framework for future studies on defensive strategies, contributing to a better understanding of animal evolution. 
Table 2. List of species observed in the present study that displayed the balling behavior or head hiding behavior.

\begin{tabular}{lll}
\hline Species & Balling behavior & Head hiding \\
\hline Aniliidae & & X \\
Anilius scytale (Linnaeus, 1758) & & $\mathrm{X}$ \\
Anomalepididae & & $\mathrm{X}$ \\
Liotyphlops beui (Amaral, 1924) & $\mathrm{X}$ & $\mathrm{X}$ \\
Liotyphlops ternetzii (Boulenger, 1896) & & $\mathrm{X}$ \\
Boidae & $\mathrm{X}$ & $\mathrm{X}$ \\
Boa constrictor Linnaeus, 1758 & $\mathrm{X}$ & $\mathrm{X}$ \\
Corallus caninus (Linnaeus, 1758) & $\mathrm{X}$ \\
Corallus hortulana (Linnaeus, 1758) & $\mathrm{X}$ \\
Epicrates assisi Machado, 1945 & $\mathrm{X}$ \\
Epicrates cenchria (Linnaeus, 1758) & $\mathrm{X}$ \\
Epicrates crassus Cope, 1862 & $\mathrm{X}$ \\
Eunectes murinus (Linnaeus, 1758) & & $\mathrm{X}$ \\
Eunectes notaeus Cope, 1862 & &
\end{tabular}

\section{Colubridae}

Drymarchon corais (Boie, 1827)

Simophis rhinostoma (Schlegel, 1837)

Spilotes pullatus (Linnaeus, 1758)

Tantilla melanocephala (Linnaeus, 1758)

\section{Dipsadidae}

Atractus pantostictus Fernandes and Puorto, 1993

$X$

Atractus paraguayensis Werner, 1924

Atractus reticulatus (Boulenger, 1885)

Atractus snethlageae Cunha and Nascimento, 1983

Boiruna maculata (Boulenger, 1896)

Clelia clelia (Daudin, 1803)

Clelia plumbea (Wied-Neuwied, 1820)

Dipsas albifrons (Sauvage, 1884)

Dipsas alternans (Fischer, 1885)

Dipsas bucephala (Shaw, 1802)

Dipsas catesbyi (Sentzen, 1796)

Dipsas indica Laurenti, 1768

Dipsas mikanii (Schlegel, 1837) 
Table 2. Continued.

\begin{tabular}{|c|c|c|}
\hline Species & Balling behavior & Head hiding \\
\hline Dipsas variegata (Duméril, Bibrón, and Duméril, 1854) & $x$ & $x$ \\
\hline Dipsas petersi Hoge and Romano-Hoge, 1975 & $x$ & $x$ \\
\hline Dipsas turgida Cope, 1868 & & $x$ \\
\hline Dipsas ventrimaculata (Boulenger, 1885) & $x$ & $X$ \\
\hline Echinanthera cephalostriata Di-Bernardo, 1996 & & $x$ \\
\hline Echinanthera cyanopleura (Cope, 1885) & & $x$ \\
\hline Erythrolamprus aesculapii (Linnaeus, 1758) & & $x$ \\
\hline Gomesophis brasiliensis (Gomes, 1918) & $x$ & $x$ \\
\hline Helicops angulatus (Linnaeus, 1758) & & $x$ \\
\hline Helicops carinicaudus (Wied-Neuwied, 1824) & $x$ & $X$ \\
\hline Helicops infrataeniatus Jan, 1865 & $x$ & $x$ \\
\hline Helicops leopardinus (Schlegel, 1837) & $x$ & $x$ \\
\hline Helicops polylepis Günther, 1861 & & $x$ \\
\hline Imantodes cenchoa (Linnaeus, 1758) & $x$ & $x$ \\
\hline Leptodeira annulata (Linnaeus, 1758) & $x$ & $x$ \\
\hline Erythrolamprus almadensis (Wagler, 1824) & & $x$ \\
\hline Erythrolamprus atraventer (Dixon and Thomas, 1985) & $x$ & \\
\hline Erythrolamprus frenatus (Werner, 1909) & $x$ & $x$ \\
\hline Erythrolamprus jaegeri (Günther, 1858) & $x$ & $x$ \\
\hline Erythrolamprus miliaris (Linnaeus, 1758) & & $x$ \\
\hline Erythrolamprus poecilogyrus (Wied-Neuwied, 1824) & & $x$ \\
\hline Erythrolamprus reginae (Linnaeus, 1758) & & $x$ \\
\hline Mussurana bicolor (Peracca, 1904) & & $X$ \\
\hline Mussurana montana Franco, Marques, and Puorto, 1997 & & $X$ \\
\hline Mussurana quimi Franco, Marques, and Puorto, 1997 & & $x$ \\
\hline Oxyrhopus clathratus Duméril, Bibrón, and Duméril, 1854 & $x$ & $X$ \\
\hline Oxyrhopus formosus (Wied-Neuwied, 1820) & & $X$ \\
\hline Oxyrhopus guibei Hoge and Romano, 1977 & & $x$ \\
\hline Oxyrhopus melanogenys (Tschudi, 1845) & & $x$ \\
\hline Oxyrhopus petolarius (Linnaeus, 1758) & & $X$ \\
\hline Oxyrhopus rhombifer Duméril, Bibrón, and Duméril, 1854 & $x$ & $x$ \\
\hline Oxyrhopus trigeminus Duméril, Bibrón, and Duméril, 1854 & & $x$ \\
\hline Paraphimophis rusticus (Cope, 1878) & $x$ & $x$ \\
\hline Philodryas aestiva Duméril, Bibrón, and Duméril, 1854 & $x$ & $X$ \\
\hline Philodryas nattereri (Steindachner, 1870) & $x$ & \\
\hline
\end{tabular}


Table 2. Continued.

\begin{tabular}{|c|c|c|}
\hline Species & Balling behavior & Head hiding \\
\hline Philodryas olfersii (Lichtenstein, 1823) & $x$ & \\
\hline Phimophis guerini (Duméril, Bibrón, and Duméril, 1854) & & $x$ \\
\hline Pseudoboa coronata Schneider, 1801 & & $X$ \\
\hline Pseudoboa haasi (Boettger, 1905) & $x$ & $X$ \\
\hline Pseudoboa nigra (Duméril, Bibrón, and Duméril, 1854) & & $x$ \\
\hline Pseudoeryx plicatilis (Linnaeus, 1758) & & $x$ \\
\hline Psomophis joberti (Sauvage, 1884) & $x$ & \\
\hline Psomophis obtusus (Cope, 1863) & $x$ & \\
\hline Psomophis sp. & & $x$ \\
\hline Ptychophis flavovirgatus Gomes, 1915 & $x$ & $x$ \\
\hline Rhachidelus brazili Boulenger, 1908 & $x$ & $x$ \\
\hline Sibon nebulatus (Linnaeus, 1758) & $x$ & \\
\hline Siphlophis cervinus (Laurenti, 1768) & $x$ & $x$ \\
\hline Siphlophis compressus (Daudin, 1803) & $x$ & $x$ \\
\hline Siphlophis pulcher (Raddi, 1820) & $x$ & $x$ \\
\hline Siphlophis worontzowi (Prado, 1940) & $x$ & \\
\hline Sordellina punctata (Peters, 1880) & & $x$ \\
\hline Taeniophallus bilineatus (Fischer, 1885) & $x$ & $x$ \\
\hline Taeniophallus occipitalis (Jan, 1863) & & $x$ \\
\hline Thamnodynastes hypoconia (Cope, 1860) & & $x$ \\
\hline Thamnodynastes strigatus (Günther, 1858) & & $x$ \\
\hline Tomodon dorsatus Duméril, Bibrón, and Duméril, 1854 & $x$ & $x$ \\
\hline Tropidodryas serra (Schlegel, 1837) & & $x$ \\
\hline Tropidodryas striaticeps (Cope, 1870) & & $X$ \\
\hline Xenodon dorbignyi (Bibrón, 1854) & & $x$ \\
\hline Xenodon guentheri Boulenger, 1894 & & $x$ \\
\hline Xenodon matogrossensis (Scrocchi and Cruz, 1993) & & $x$ \\
\hline Xenodon neuwiedii Günther, 1863 & & $x$ \\
\hline Xenopholis scalaris (Wucherer, 1861) & $x$ & \\
\hline Xenopholis undulatus (Jensen, 1900) & $X$ & \\
\hline \multicolumn{3}{|l|}{ Elapidae } \\
\hline Micrurus altirostris (Cope, 1860) & & $x$ \\
\hline Micrurus corallinus (Merrem, 1820) & & $x$ \\
\hline Micrurus decoratus (Jan, 1858) & & $X$ \\
\hline Micrurus ibiboboca (Merrem, 1820) & & $x$ \\
\hline
\end{tabular}


Table 2. Continued.

\begin{tabular}{|c|c|c|}
\hline Species & Balling behavior & Head hiding \\
\hline Micrurus lemniscatus (Linnaeus, 1758) & & $x$ \\
\hline Micrurus pyrrhocryptus (Cope, 1862) & & $x$ \\
\hline Micrurus tricolor (Hoge, 1956) & & $x$ \\
\hline \multicolumn{3}{|l|}{ Leptotyphlopidae } \\
\hline Trilepida brasiliensis (Laurent, 1949) & $x$ & \\
\hline \multicolumn{3}{|l|}{ Tropidophiidae } \\
\hline Tropidophis paucisquamis (Müller, 1901) & $x$ & $x$ \\
\hline \multicolumn{3}{|l|}{ Typhlopidae } \\
\hline Amerotyphlops brongersmianus (Vanzolini, 1976) & $x$ & $x$ \\
\hline \multicolumn{3}{|l|}{ Viperidae } \\
\hline Bothrops bilineatus (Wied-Neuwied, 1821) & & $x$ \\
\hline Bothrops diporus Cope, 1862 & & $x$ \\
\hline Bothrops erythromelas Amaral, 1923 & & $x$ \\
\hline Bothrops itapetiningae (Boulenger, 1907) & & $x$ \\
\hline Bothrops neuwiedi Wagler, 1824 & & $x$ \\
\hline Bothrops jararaca (Wied-Neuwied, 1824) & $x$ & $x$ \\
\hline Bothrops moojeni Hoge, 1966 & & $x$ \\
\hline Bothrops alternatus Duméril, Bibrón, and Duméril, 1854 & & $x$ \\
\hline Bothrops cotiara (Gomes, 1913) & $x$ & $X$ \\
\hline Bothrops fonsecai Hoge and Belluomini, 1959 & $x$ & $x$ \\
\hline
\end{tabular}

\section{Acknowledgments}

We are deeply indebted to Editor Jaime Bertoluci, Associate Editor J. P. Lawrence, and two anonymous reviewers for their corrections, comments, and suggestions to our manuscript. We thank Fausto E. Barbo, Ivan Sazima, Otávio A. V. Marques, Paula H. Valdujo, and Paulo A. Hartmann for having kindly provided unpublished information, and Fernanda Stender, Paula H. Valdujo and Julián Faivovich for photographs. FAPESP and CNPq provided grants and fellowships to LFT; CAPES, CNPq (310859/20204), and FAPERGS provided grants to AMT, DL and OME-N. Daniel Loebmann thanks CNPq for a research grant (310859/2020-4).

\section{References}

Bustard, H. R. 1969. Defensive behavior and locomotion of the Pacific Boa, Candoia aspera, with a brief review of head concealment in snakes. Herpetologica 25: 164170.

Costa, H. C. and R. S. Bérnils. 2018. Répteis do Brasil e suas Unidades Federativas: Lista de espécies. Herpetologia Brasileira 7: 11-57.

Dawkins, R. and J. R. Krebs. 1979. Arms races between and within species. Proceedings of the Royal Society of London, Series B 205: 489-511.

Figueroa, A., A. D. McKelvy, L. L. Grismer, C. Bell, and S. P. Lailvaux. 2016. A species-level phylogeny of extant snakes with description of a new colubrid subfamily and genus. PloS ONE 11: e0161070. 
Greene, H. W. 1973. Defensive tail display by snakes and amphisbaenians. Journal of Herpetology 7: 143-161.

Greene, H. W. 1983. Dietary correlates of the origin and radiation of snakes. American Zoologist 23: 431-441.

Greene, H. W. 1988. Antipredator mechanisms in reptiles. Pp. 1-152 in C. Gans and R. B. Huey (eds.), Biology of the Reptilia. New York. John Wiley and Sons.

Greene, H. W. 1997. Snakes: The Evolution of Mystery in Nature. Berkeley. Berkeley University California Press. $366 \mathrm{pp}$.

Lewis, T. R. and O. J. J. Lewis. 2010. Defensive behavior in Dipsas articulata (Cope, 1868). Herpetozoa 23: 79-81.

Louca, S., and M. S. Louca. 2017. Package 'castor'.

Mitchell, J. C. 1978. Balling behavior in Chionactis occipitalis (Reptilia, Serpentes, Colubridae). Journal of Herpetology 12: 435-436.
Michonneau, F., J. W. Brown, and D. J. Winter. 2016. rotl: an $\mathrm{R}$ package to interact with the Open Tree of Life data. Methods in Ecology and Evolution 7: 1476-1481.

Pough, F. H., R. H. Andrews, M. L. Crump, A. H. Savitzky, K. D. Wells, and M. C. Brandley. 2016. Herpetology. 4th edition. Upper Saddle River. Pearson Pretince Hall. 744 pp.

Revell, L. J. 2012. phytools: an R package for phylogenetic comparative biology (and other things). Methods in Ecology and Evolution 3: 217-223.

Ruxton, G. D., T. N. Sherratt, M. P. Speed. 2004. Avoiding Attack: The Evolutionary Ecology of Crypsis, Warning Signals and Mimicry. New York. Oxford University Press. 249 pp.

Tozetti, A. M., R. B. Oliveira, and G. M. F. Pontes. 2009. Defensive repertoire of Xenodon dorbignyi (Serpentes, Dipsadidae). Biota Neotropica 9: 157-163.

Editor: J. P. Lawrence 